\title{
Rare pulmonary tumours: a histological and radiological overview
}

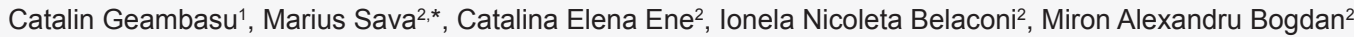

${ }^{1}$ Buzau County Hospital, Respiratory Department, Romania

2"Marius Nasta" Institute of Pneumophthisiology, 4th Department, Bucharest, Romania

Abstract

\section{English:}

Adenocarcinoma, squamous cell carcinoma, and small cell carcinoma represent about $95 \%$ of lung tumours. However, the lung is the site of numerous types of tumours that may have an epithelial, mesenchymal, neuroendocrine, or lymphohematopoietic origin. With minor exceptions, both the clinical manifestations and the imaging characteristics are non-specific; many of the low-incidence tumours have common features with the high-incidence tumours. This article presents a group of low-incidence pulmonary tumours that pose multiple difficulties in terms of diagnosis due to non-specific symptomatology and non-specific imaging aspect. This article aims to correlate the histological data with imaging aspects to facilitate diagnostics. Because these tumours are rare and because they present in a variety of forms, problems may occur when establishing a diagnosis and trying to predict their behaviour. It is challenging to differentiate common lung tumours from rare ones based on clinical, radiological, or histological features. Only the presence of the imaging particularities, such as the location of the lesion, the association with certain patterns (appearance of ground glass, the "halo" sign, the presence of calcifications), and the histological/immunohistochemical profile can lead to the establishment of a correct diagnosis.

Keywords

lung tumours $•$ low incidence $\bullet$ non-specific appearance $\bullet$ imaging/histopathological aspect

\section{Tumori pulmonare rare - o trecere în revistă histologică și radiologică}

Rezumat

\begin{abstract}
Romanian:
Adenocarcinomul, carcinomul scuamos și carcinomul cu celule mici reprezintă aproximativ 95\% din totalul tumorilor pulmonare, însă plămânul reprezintă sediul a numeroase tipuri de formațiuni tumorale care pot avea origine epitelială, mezenchimală, neuroendocrină, limfo-hematopoietică și care reunesc aproximativ 5\% din totalul tumorilor pulmonare. Cu mici excepții, atât manifestările clinice cât și aspectul imagistic sunt nespecifice, multe din ele având caractere comune cu celelalte tumori cu incidență ridicată. Acest articol prezintă un grup de tumori pulmonare cu incidență scăzută care pune multiple dificultăți atât în ceea ce privește diagnosticul, din cauza simptomatologiei nespecifice, cât și a aspectului imagistic nesugestiv și greu de diferențiat. Scopul articolului este de a corela datele histologice cu aspectul imagistic în vederea ușurării demersului diagnostic. Dată fiind multitudinea de forme atât histologice cât și imagistice întâlnite în cadrul unui grup restrâns de tumori ca și incidență, acestea pot pune reale probleme atât de diagnostic cât și de conduită terapeutică, fiind greu de diferențiat clinic, imagistic sau histologic de tumori pulmonare des întâlnite în practica medicală. Doar prezența particularităților imagistice, cum ar fi localizarea leziunii, asocierea cu anumite patternuri (aspect de sticlă mată, semnul,,haloului,, prezența calcificarilor) cât și profilul histologic/ imunohistochimic pot duce la stabilirea cu certitudine a unui diagnostic corect.
\end{abstract}

Cuvinte-cheie

tumori pulmonare • incidență scăzută• aspect nespecific • aspect imagistic/histopatologic

${ }^{*}$ Corresponding author: Marius Sava

E-mail: dr.savamarius@yahoo.com

ə Open Access. @ 2020 Geambasu et al., published by Sciendo

(cc) Br-Nc-ND This work is licensed under the Creative Commons Attribution-NonCommercial-NoDerivs 4.0 License. 


\section{Introduction}

Lung cancer is a leading cause of cancer mortality. The main histological types of lung cancer are adenocarcinoma, squamous cell carcinoma, and endocrine small cell carcinoma (1). Together they represent $99 \%$ of lung tumours. In most cases, differentiating rare pulmonary tumours from typical neoplasms is a challenge because they do not have any particular clinical expression, and the radiological examination cannot provide conclusive data. Given this diagnostic uncertainty, in most situations, a histological examination of a tissue biopsy is necessary (2).

This article presents a group of low-incidence pulmonary tumours that pose multiple difficulties in terms of diagnosis due to non-specific symptomatology and non-specific tomographic aspects. This article aims to correlate the histological data with the radiological elements to facilitate the diagnostic approach.

\section{Historical data}

Steele published the first research on this subject in 1963. The study included 882 male patients who underwent lung resection. Thirty-six per cent of the patients had malignant tumours, while $64 \%$ had benign tumours. In terms of localisation, $94 \%$ of the tumours were parenchymal and $6 \%$ endobronchial. One limitation of the study was the absence of computed tomography (CT) scans (1).

A study conducted by Mayo Clinic in 1993 approached the subject of both benign and malignant lung tumours with low incidence; the data are presented in Table 1. Among benign tumours, hamartoma had the highest incidence representing $77 \%$, whereas in malignant tumours, lymphoma and carcinosarcoma were the most common $(1,2)$.

Another study regarding rare pulmonary tumours, conducted at The National Matsudo Hospital and The National Cancer Hospital East - Japan developed on a group of 3,481 patients, from 1976 to 1995, identified 20 malignancies and 12 benign tumours. Malignant lymphoma was the most common malignant tumour (six cases), while papilloma, lipoma, and leiomyoma were the most common benign tumours (three cases). The results are described in Table 2 (3).

\section{Lung epithelial tumours}

\section{Tumours with endobronchial location}

\section{Carcinoid tumours}

The primary lung carcinoid is a neuroendocrine tumour that has an endobronchial localisation primarily, and it represents
Table 1. Histopathological diagnoses of 80 rare primary pulmonary neoplasms (Mayo Clinic, 1980-1990)

\begin{tabular}{lc}
\hline Types of neoplasm & Patients no (\%) \\
\hline Lymphoma & $33(41)$ \\
$\cdot$ Small cell & 22 \\
• Large cell & 6 \\
• Mixed cell & 5 \\
Carcinosarcoma & $16(20)$ \\
Mucoepidermoid carcinoma & $12(15)$ \\
Malignant fibrous histiocytoma & $4(5)$ \\
Malignant melanoma & $3(4)$ \\
Fibrosarcoma & $3(4)$ \\
Leiomyosarcoma & $3(4)$ \\
Angiosarcoma & $2(2)$ \\
Haemangiopericytoma & $2(2)$ \\
Osteosarcoma & $1(1)$ \\
Blastoma & $1(1)$ \\
\hline
\end{tabular}

Table 2. Histopathological diagnosis of 32 rare primary pulmonary neoplasms (National Matsudo Hospital and National Cancer Hospital East - Japan)

\begin{tabular}{lc}
\hline Types of malignant tumours $(\boldsymbol{n}=\mathbf{2 0})$ & Patients no (\%) \\
\hline Epithelial tumours & $1(5)$ \\
Adenocystic carcinoma & $2(10)$ \\
Mucoepidermoid carcinoma & $2(10)$ \\
Bronchial gland mixed tumour & $1(5)$ \\
Myoepitelioma & \\
Soft tissue tumours & $1(5)$ \\
Leiomyosarcoma & $1(5)$ \\
Epitheloid haemangioendothelioma & $1(5)$ \\
Hemangiopericytoma & \\
Miscellaneous tumours & $3(15)$ \\
Carcinosarcoma & $1(5)$ \\
Malignant melanoma & $6(30)$ \\
Malignant lymphoma & $1(5)$ \\
Coriocarcinoma & Patients no (\%) \\
\hline Types of benign tumours $(\boldsymbol{n}=\mathbf{1 2})$ & \\
\hline Epithelial tumours & $3(25)$ \\
Papillomas & $1(8.3)$ \\
Adenomas & \\
Soft tissue tumours & $1(8.3)$ \\
Fibromas & $3(25)$ \\
Lipoma & $3(25)$ \\
Leiomyoma & \\
Miscellaneous tumours & $1(8.3)$ \\
Meningioma &
\end{tabular}

$0.5-2.5 \%$ of lung tumours. There are two types of carcinoid tumours, namely, typical (80-90\%) and atypical (10-20\%). The average age of presentation is 45 years. In terms of location, this tumour has a predilection for subsegmental 
bronchi. Most carcinoid tumours have a sizeable extraluminal component, which is why they have been called "iceberg lesions" $(4,5)$.

Imagistically, it presents as a solitary nodule or mass, with a round or oval shape and a slightly lobed margin; rarely, it may present irregular edges (Figure 1). Calcifications can be distinguished in up to $30 \%$ of the patients (5). In some cases, carcinoid tumours can cause consolidations or atelectasis by obstructing a segmental bronchus (4). The atypical form of the carcinoid tumour was more associated with the occurrence of hilar and mediastinal adenopathies $(6,7)$.

Histologically, the tumour contains multiple interconnected trabeculae separated by vascular stroma with numerous blood vessels with thin walls. The differences between the two forms, typical and atypical, are (a) mitotic activity, (b) cytological pleomorphism, (c) necrosis zones, (d) cell distribution, and (e) the presence of distortions (Figure 2).

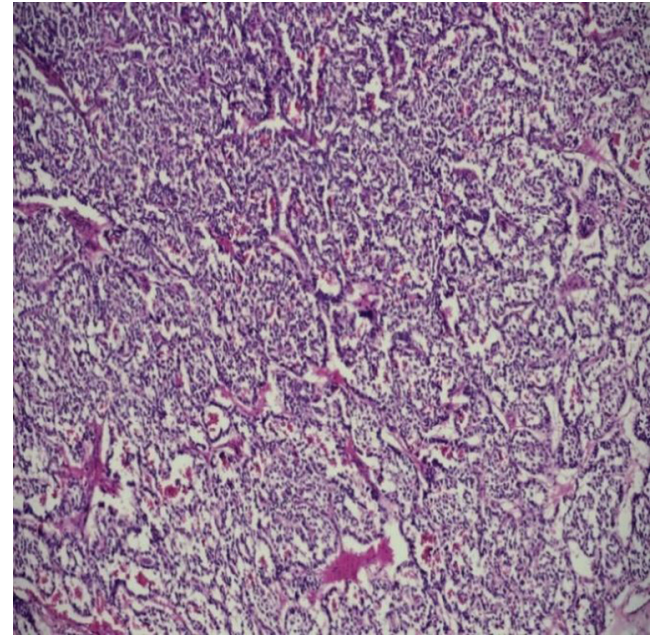

Figure 1. Interconnected trabeculae, separating from a vascular stroma - carcinoid tumor (H\&E 10X).

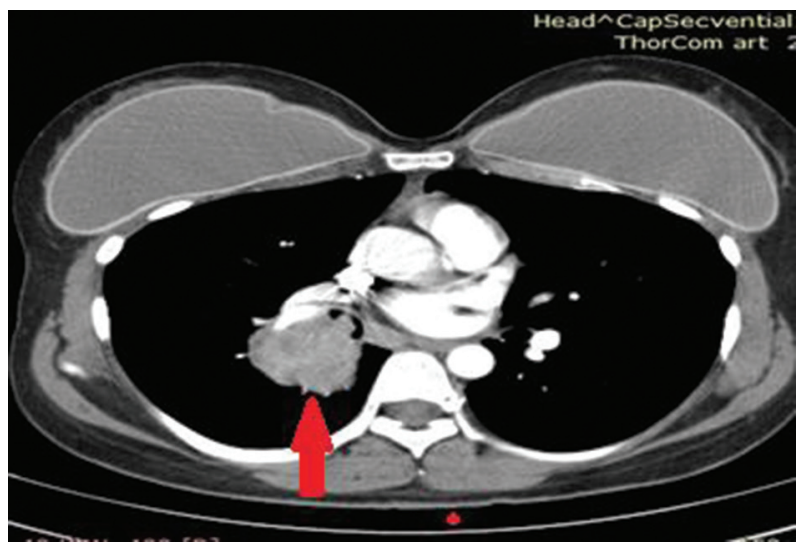

Figure 2. CT examination - Female pacient with a round hilar mass with irregular inferior edge - atypical carcinoid tumor.

\section{Tracheobronchial papillomatosis}

Airway papillomatosis is a benign tumour of the tracheobronchial tree of squamous-epithelial origin. In many cases, glandular elements can also be found in its structure. It has been associated with the human papilloma virus infection, most likely by vertical transmission, and it occurs more frequently in the proximal airways (2).

Lung parenchymal involvement occurs as a major complication of airway papillomatosis. This tumour presents the risk of relapse after many years of latency. The most severe complication is the malignant transformation. Patients with pulmonary papillomatosis have an increased risk of developing squamous carcinoma (histologically, it presents a well-differentiated cytological structure without anaplastic transformation characteristics despite the tendency for accelerated growth).

Computer tomography detects a tumour with a pedunculated or sessile aspect that presents a tendency to form cystic opacities, located predominantly in the posterior lung segments (6).

\section{Tracheobronchial gland tumours}

Among tumours with tracheal localisation, tracheobronchial gland tumours, in particular, cystic adenoid carcinoma, are the second most frequent after squamous carcinoma.

The tumour is usually situated intraluminally; thus, it has clinical expression. The patients can present symptoms and signs of obstruction as well as haemoptysis (6).

The histological structure is composed of small cells with a hypochromic nucleus and few mitoses.

The CT image may reveal a solitary nodule, sometimes with punctual calcifications. More often, because the tumour has an endoluminal localisation, post-obstructive pneumonia occurs, and consolidations become visible on the CT scans. In these tumours, the most important challenge is to classify the degree of malignancy. However, even in advanced stages, it shows better evolution and prognosis than bronchogenic carcinoma (4).

\section{Tumours of mesenchymal origin}

\section{Tumours with parenchymal localisation}

\section{Pulmonary haemangioma}

Pulmonary sclerosing haemangioma is a low-incidence pulmonary tumour with uncertain histology; the latest research suggests that it has an epithelial origin. It occurs more often in young and middle-aged women.

Histologically, it presents a network of multiple thin-walled vessels and poorly represented stroma $(2,4)$. The nucleus has numerous atypia with rare mitoses. The tumour contains 
two cell types: surface cells and round cells. Based on cell arrangements, there are four types of pulmonary haemangioma, namely, papillary, sclerotic, solid, and haemorrhagic.

Radiologically, they are described as round or ovoid formations located in the peripheral regions of the pulmonary parenchyma, most frequently in the subpleural area, preferentially in the right lung (6).

The differential diagnosis between "true" haemangioma and arteriovenous malformations is essential. The latter is not considered a tumour formation, but rather a congenital vascular malformation.

Most commonly, they are asymptomatic because their vessels are infused into the pulmonary circulation. If they become large, they may lead to the appearance of a right-left shunt, associating symptoms such as cyanosis, polycythaemia, and clubbing (2).

\section{Lipoma}

Despite being one of the most common benign lung tumours, pulmonary lipoma is a rare tumour but also among the first pulmonary tumours reported in the literature by Rokitansky in 1854. They appear more commonly in middle-aged men $(8,9)$. Histologically, it consists of well-known nodules that are composed of mature adipocytes. CT scans will reveal welldefined nodular lesions or pulmonary masses with either endobronchial disposition, central disposition, or a peripheral one. Endobronchial lipomas are most often pedunculated $(2,4,6)$, (Figure 3).

\section{Liposarcoma}

Primary pulmonary liposarcoma is one of the rarest forms of sarcoma with pulmonary localisation. Histologically, malignant lipoblasts are present with the ability of neoangiogenesis and nuclear polymorphism.

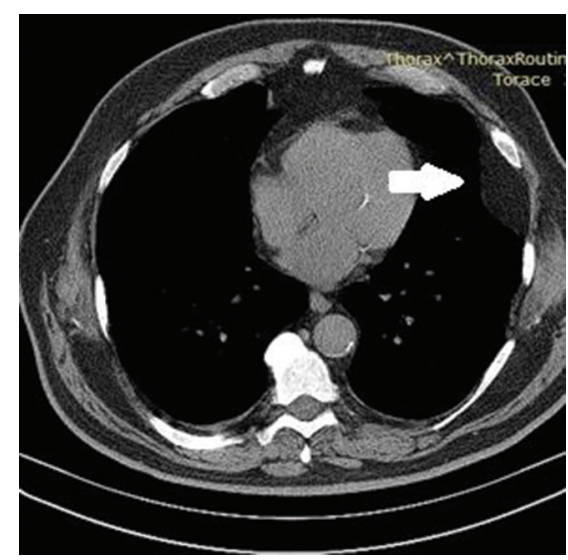

Figure 3. CT scan - Peripheral tumor with well defined border pulmonary lipoma.
Imagistically, the liposarcoma is frequently described as a large heterogeneous mass with lipomatous structure and well-differentiated edges (Figure 4). This type of lesion should be distinguished from other lipomatous lesions such as pulmonary lipoma, pulmonary hamartoma, and lipoid pneumonia (6).

\section{Mesenchymal tumours}

\section{Pulmonary hamartoma}

It is the most common benign pulmonary tumour, and it represents between 5 and $8 \%$ of the solitary pulmonary nodules. It occurs predominantly in male patients in the fifth and sixth decades of life (10).

Imagistically, the hamartoma is a well-defined lung nodule. The characteristic "popcorn" aspect is described when the tumour presents central calcifications (Figure 5). The hamartoma is
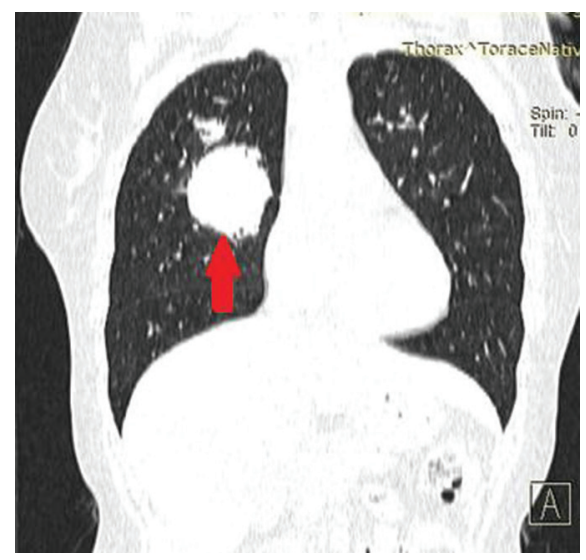

Figure 4. CT Scan - Large round mass with irregular edges localized in the right lung - Liposarcoma.

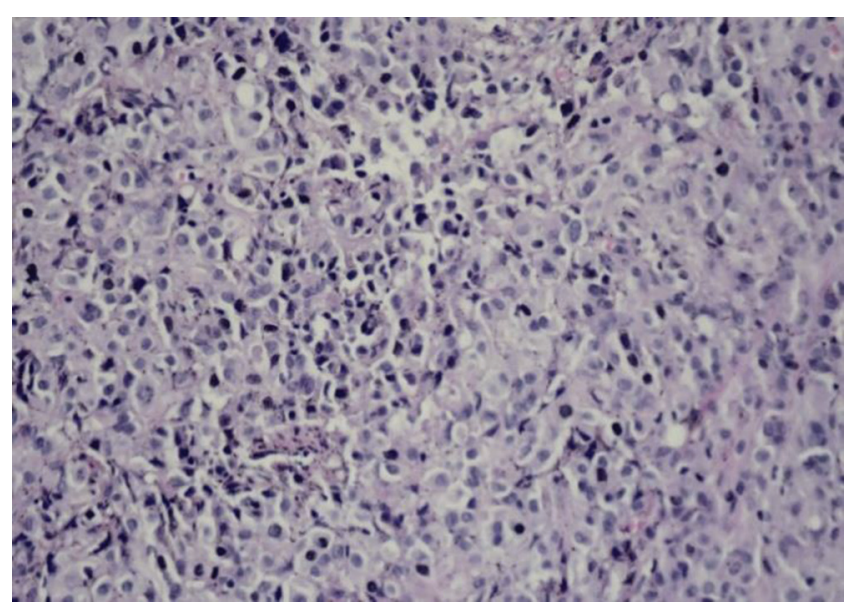

Figure 5. Multiple mesenchymal and epithelial elements without necrosis - Hamartoma (H\&E 10X). 
considered to be a true neoplasm of bronchial mesenchymal tissue, having a variety of differentiation capabilities (11).

Histologically, it consists of a combination of mesenchymal elements (mixoid and fibromixoid elements) and epithelial elements, with the absence of necrosis (Figure 6).

Mesenchymal tumours with vascular structure are subtypes of mesenchymal tumors

\section{Angiosarcoma of the lung}

The primary pulmonary angiosarcoma is rarer than metastasic pulmonary lesions of heart angiosarcomas. Primary pulmonary angiosarcoma usually occurs in middle-aged adults, and in most cases, patients present haemoptysis, which is unresponsive to treatment.

Histological analysis shows positive keratin cells with rare atypia (Figure 7). The CT exam reveals the presence of pulmonary masses or nodules that have similar densities to the muscle tissue (Figure 8). Most commonly, these tumours can invade the mediastinum, including the trachea, the thoracic wall, and both the pleura and the pericardium, causing fluid accumulation. The most common radiological sign of the lung angiosarcoma is the "halo sign" describing a central soft tissue area surrounded by a glass-glazing halo.

Differential diagnosis is necessary to rule out other pathologies that may present a halo sign (granulomatosis with polyangiitis or Kaposi's sarcoma) (6).

\section{Tumours of the lymphatic system}

Primary lung lymphomas are a rare form of lymphoma, accounting for about $1 \%$ of lung malignancies. The definition of primary pulmonary lymphoma over time has undergone multiple changes; presently, it is defined as the proliferation

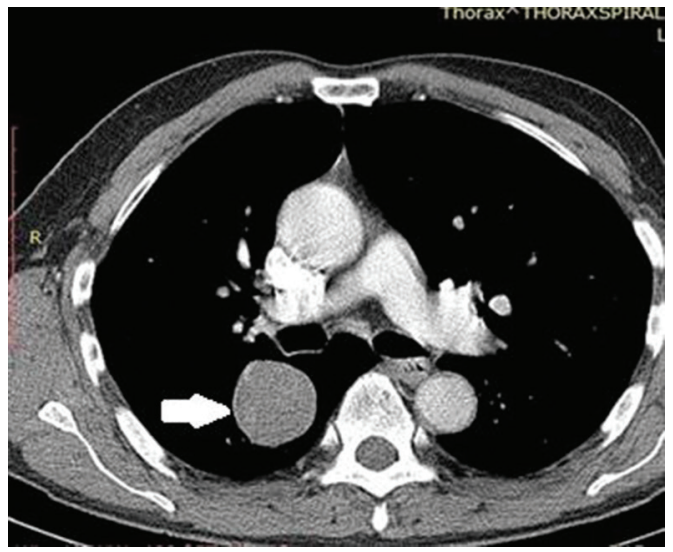

Figure 6. CT Scan - Well-defined lung mass, without necrosis but with slighty calcifications - Hamartoma. of lymphoid clones without another localisation, besides the lung, at least 3 months after diagnosis.

There are three phenotypes, each with its features and particular radiological description (6).

a) Angiocentric lymphoma, formerly called lymphoid granulomatosis, was initially considered a form of vasculitis with malignant transformation potential.

Histological analysis reveals the presence of interstitial lymphoid infiltration with an angiocentric pattern, central necrosis, and a cavitation tendency. Sometimes, a variablesized vessel is present in the centre of the lesion, justifying

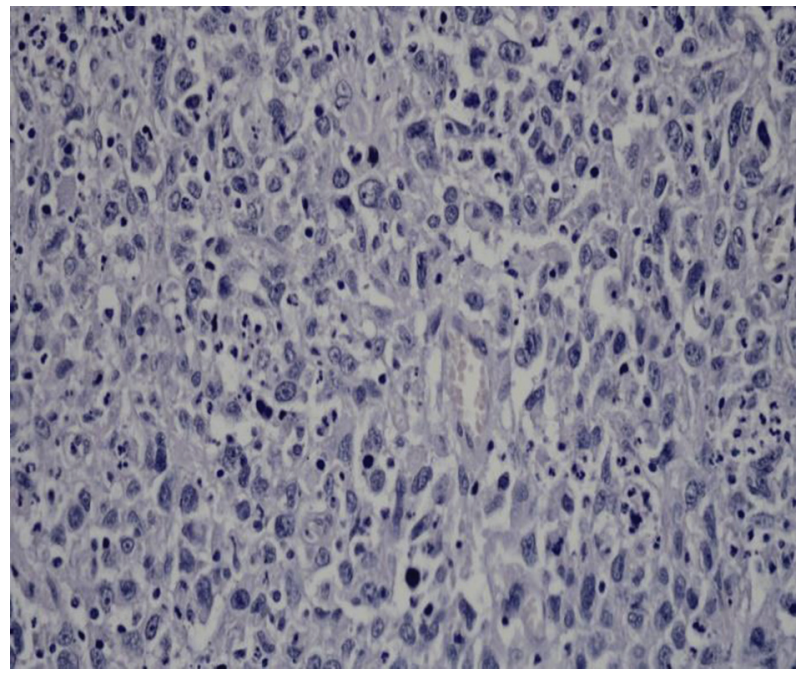

Figure 7. Cells with keratin with few atypia - Angiosarcoma (H\&E 10X).

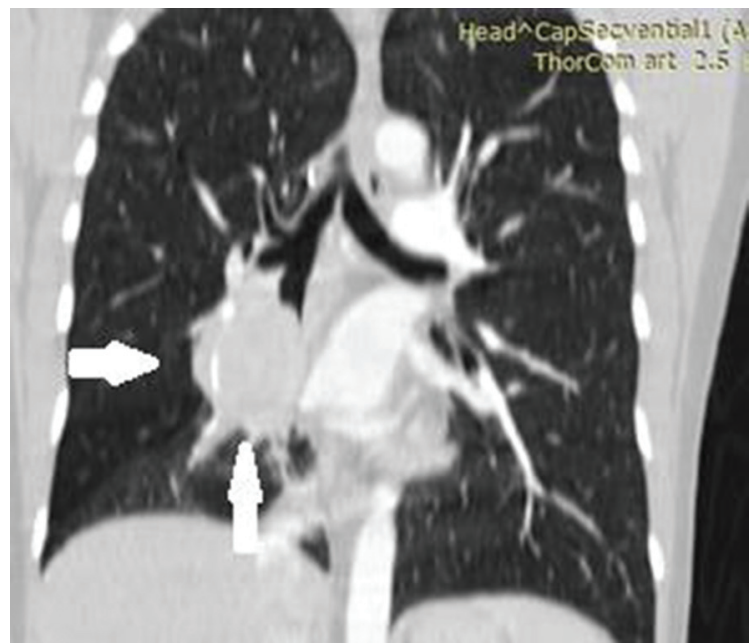

Figure 8. CT scan - Large central tumor situated in middle and lower lobe with spiculate margins - pulmonary angiosarcoma. 


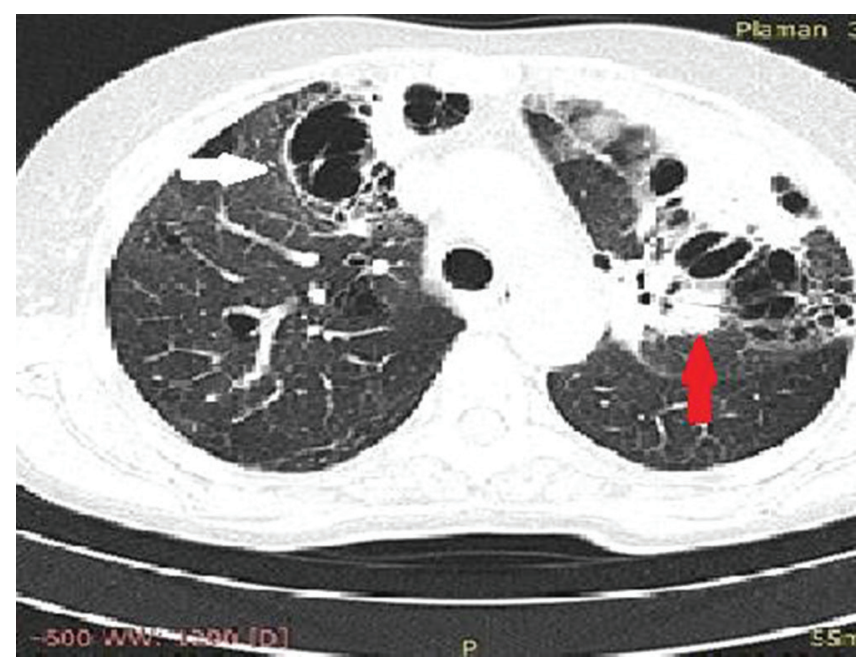

Figure 9. CT scan - Multicentric masses (red arrow) with central bronchiectasis and necrosis (white arrows) - pulmonary Angiocentric Lymphoma.

its name-angiocentric lymphoma. Immunohistochemically, most lymphoid cells are CD4-positive.

CT scans reveal soft-tissue nodules situated in both lungs, predominantly in the upper lung segments. Pleural involvement occurs in about $30 \%$ of cases (12) (Figure 9).

b) Low-grade small B-cell lymphoma of BALT origin. Namely, pulmonary pseudolymphoma is the most common phenotype of primary pulmonary lymphoma, with origin in mucosal-associated lymphoid tissue (4). Its slow growth rate justifies the name of pseudolymphoma.

The mean age incidence is between 25 and 85 years, both sexes being equally affected. Approximately half of the cases are asymptomatic at the time of diagnosis. Cell type and disease status at diagnosis are the main prognostic factors.

Histologically, it presents areas of non-necrotising lymphoproliferative infiltrations with the preservation of the pulmonary architecture. Most commonly, BALT lymphoma has a typical lymphocyte pattern (13).

Imagistically, the typical aspect is that of a solitary pulmonary mass with variable dimensions $(2-8 \mathrm{~cm})$, but it can take various forms. Rarely, multiple or bilateral nodular lesions, infiltration of the bronchial vascular structures or the interlobar septa, or infiltrative appearance similar to a pneumonic area may be present. Frequently, the nodular lesions associate ground-glass areas. The involvement of lymph nodules occurs in approximately $30 \%$ of the cases $(4,13)$.

\section{Conclusions}

Diagnosing and treating rare pulmonary tumours can be a challenge. Differential diagnosis between high-incidence lung tumours and rare tumours can also be particularly difficult because of their various clinical, radiological, and histological forms.

The presence of certain specific radiological features, such as localisation, the halo sign, and the popcorn sign together with a compatible histological/immunohistochemical profile, can establish a correct diagnosis.

\section{References}

1. Miller DL, Allen MS. Rare pulmonary neoplasms. Mayo Clinic Proceedings. 1993;68: 492-498.

2. Allan JS. Rare solitary benign tumors of the lung. Seminars in Thoracic and Cardiovascular Surgery. 2003;15: 315-322.

3. Sekine I, Kodama T, Yokose T, Nishiwaki Y, Suzuki K, Goto K, et al. Rare pulmonary tumors -a review of 32 cases. Oncology. 1998;55: 431-434.

4. Giménez A, Franquet T, Prats R, Estrada P, Villalba J, Bagué S. Unusual primary lung tumors: a radiologicpathologic overview. RadioGraphics. 2002;3: 601-619.

5. McMullan DM, Wood DE. Pulmonary carcinoid tumors. Seminars in Thoracic and Cardiovascular Surgery. 2003;15: 289-300.

6. Landini N, Milanese G, Zambrini E, Ariozzi I, Gnetti L, Carloni A, et al. Computed tomography - histology correlations of unusual lung tumors. Pathologica. 2016;10: 110-119.

7. Jeung MY, Gasser B, Gangi A, Charneau D, Ducroq X, Kessler $\mathrm{R}$, et al. Bronchial carcinoid tumors of the thorax: spectrum of radiologic findings. Radiographics. 2002;22: 351-365.

8. Muraoka M, Oka T, Akamine S, Nagayasu T, Iseki M, Suyama $\mathrm{N}$, et al. Endobronchial lipoma: review of 64 cases reported in Japan. Chest. 2003;123: 293-296.

9. Politis J, Funahashi A, Gehlsen JA, DeCock D, Stengel BF, Choi $\mathrm{H}$. Intrathoracic lipomas: report of three cases and review of the literature with emphasis on endobronchial lipoma. The Journal of Thoracic and Cardiovascular Surgery. 1979;77: 550-556.

10. Ahn JM, Im JG, Seo JW, Han HS, Yoon HK, Kim WS, et al. Endobronchial hamartoma: CT findings in three patients. American Journal of Roentgenology. 1994;163: 49-50.

11. Potente G, Macori F, Caimi M, Mingazzini P, Volpino P. Noncalcified pulmonary hamartomas: computed tomography enhancement patterns with histologic correlation. Journal of Thoracic Imaging. 1999;14: 101-104.

12. Gjevre JA, Myers JL, Prakash UB. Pulmonary hamartomas. Mayo Clinic Proceedings. 1996;71: 14-20.

13. Cadranel J, Wislez M, Antoine M. Primary pulmonary lymphoma. European Respiratory Journal. 2002;20: 750-762. 